\title{
Economics of Offshore IT Outsourcing: An International Trade Perspective
}

\author{
Bijoy Bordoloi*, Anne Powell \\ Computer Management and Information Systems, Southern Illinois University at Edwardsville, Edwardsville, USA \\ Email: "bbordol@siue.edu, apowell@siue.edu
}

Received June 7, 2013; revised July 7, 2013; accepted July 14, 2013

Copyright (C) 2013 Bijoy Bordoloi, Anne Powell. This is an open access article distributed under the Creative Commons Attribution License, which permits unrestricted use, distribution, and reproduction in any medium, provided the original work is properly cited.

\begin{abstract}
In recent times, offshore outsourcing of Information Technology (IT) products and services, including software development and maintenance activities, has been an issue of much controversy in the United States, with popular sentiment being against outsourcing in the mass media. Is offshore outsourcing really bad for the US economy? If yes, why did so many US companies, including IT companies, start outsourcing to begin with and still continue to do so? For that matter, why doesn't the federal government simply ban it as a national policy? To provide some possible answers to these questions, this paper examines the issue of offshore outsourcing from the perspectives of international trade theory and the unique cost characteristics of "information goods".
\end{abstract}

Keywords: Technology Economics; Economics of Offshore Outsourcing; International Trade Theory; Information Economics; Position Paper

\section{Introduction}

In recent times, offshore outsourcing (or simply "outsourcing") of service sector activities (and jobs) has grown rapidly and has been an issue of much controversy in the United States. Outsourcing is not new; in the US, it can be traced back to the 1880s when New England textile mills moved south to the Carolinas [1]. Historically, the majority of outsourced jobs were in the manufacturing sector. Today, because of technological advances, distribution costs nearing zero with the use of cloud computing and the Internet, and increased availability of skilled workers. It is the outsourcing of service sector jobs, many in the relatively high-paying Information Technology (IT) area, which is attracting attention. In a recent study, $40 \%$ of firms within the technology-services and telecommunications industry reported offshore outsourcing [2]. This paper focuses specifically on the offshore outsourcing of IT jobs. We define offshore IT outsourcing as “... the organizational decision to turn over part or all of an organization's IS functions to external service provider(s) in order for an organization to be able to achieve its goals," [3, p. 209].

As jobs are being outsourced to India, China, Mexico,

${ }^{*}$ Corresponding author. and other countries, the mass media is quick to report on the negatives and harm that outsourcing causes employees. Headlines such as "A Greater Threat than Terrorism: Outsourcing the American Economy," [4] or "Negative Effects Outsourcing has on Companies," [5] are common. Mass media pay attention to outsourcing intensifies during election years. During the US election year of 2012, outsourcing came to the forefront of election issues. Current President Barack Obama criticized his opponent, Mitt Romney, for outsourcing American jobs when Romney headed Bain Capital Corporation. Republicans, in turn, criticized President Obama for outsourcing energy jobs [6], or simply not doing enough to slow the growth of outsourcing [7].

Is offshore outsourcing really bad for the US economy? If yes, why did so many US companies, including IT companies, start outsourcing to begin with and still continue to do so? For that matter, why doesn't the federal government simply ban it as a national policy? And, if outsourcing is so bad, why did 2012 legislation to eliminate tax breaks to companies that outsource get voted down in the US Senate?

While there has been published some economic theory based research (e.g., Transaction Cost Economics [8]) in the IT literature to examine the merits of outsourcing, in 
this paper, we provide an alternate theoretical perspective based on international trade theory and the unique cost characteristics of "information goods" to provide some possible answers to the above questions.

The rest of the paper is organized as follows. In the next section, at the firm level, we describe some recently published findings regarding the benefits companies received by outsourcing work to other countries. To look at the issue of offshore outsourcing more objectively at a macro or national level, we next discuss the trade theory of Comparative Advantage to provide some basic understanding of foreign trade. Against the backdrop of this trade theory, we then discuss the winners and losers in the outsourcing battle and provide some possible answers to the questions raised above. Finally, we conclude with some future research questions that should, perhaps, be asked regarding the consequences of offshore outsourcing.

\section{Why Outsource?}

Many companies outsource. In a recent survey, $15 \%$ of all companies reported offshore outsourcing. But the same survey also showed that in $40 \%$ of the IT services and telecommunications industry companies, offshore outsourcing was occurring [2].

Research on Information technology outsourcing (ITO) has been ongoing for over twenty years. During this time, numerous studies have studied diverse topics on ITO including factors related to the decision on whether to outsource and factors related to the successful outcomes of outsourcing by companies.

Lacity et al. [9], published a comprehensive literature review on ITO in 2010 that reviewed 164 empirical articles on ITO between 1992 and 2010. The authors found four core areas that have been studied extensively on the decision to outsource. Most commonly studied is the motivation of companies to outsource. What motivates a corporation to outsource their IT function most is the need to reduce costs. Tied to the need to reduce costs is the desire of the corporation to focus on core capabilities, and a corporation's core capability may not include its IT function. This, then increases the motivation to outsource IT. In addition, access to more or better IT skills and/or expertise, and a desire for business process improvements also motivates the decision to outsource.

Alternatively, a corporation is less likely to make the decision to outsource their IT if the company has a great concern about security or fear of losing control of their IT. Transaction attributes were also a frequent topic of research on ITO decisions. The transaction attributes most commonly studied are consistently related to the decision NOT to outsource. Higher values of uncertainty, the critical role of IS, transaction costs, and business risks all lead to less outsourcing. Prior IS department performance was also significantly and negatively related to the decision to outsource while mimetic influence (perception that peer organizations are more successful) was significantly and positively related to the decision to outsource [9].

Of more interest is how companies have benefitted from Information technology outsourcing. IT outsourcing appears to occur most often because of costs savings or access to skills [2,10]. Lacity et al. [9], report that outsourcing IT results in a positive outcome $63 \%$ of the time, and no changes in performance $15 \%$ of the time. Only $22 \%$ of the outsourcing outcomes were negative. Outsourcing has been found to reduce costs $[11,12]$, increase exports [11,13], improve productivity and enhance an organization's flexibility [14] and increase new product innovation [11].

In this paper we posit that offshore outsourcing, effectively, can be viewed as "international trade" and nations (and companies) benefit considerably from international trade. To understand the economic benefits of international trade, next we discuss the theoretical roots of the modern day trade developed by David Ricardo (17721823), known as the Principle of Comparative Advantage [15].

\section{The Theory of Comparative Advantage}

Adam Smith (1723-1790), a classical economist, was a champion of free trade or open markets. He argued that free trade enables each trading nation to benefit considerably by specializing in the production of goods that it produces at a lower cost than the other nation, while importing the good that it produces at a higher cost. Unlike Smith, who emphasized the importance of absolute cost differences among nations, Ricardo emphasized relative or comparative cost differences. Ricardo showed that mutually beneficial trade can occur even if one nation is absolutely more efficient in production of all goods than its trading partner.

To understand Ricardo's trade theory based on comparative cost advantage, to keep things simple, let us consider only two nations: US and India, and only two goods: Aircraft and Software, as exemplars. As shown in Table 1, suppose that the US can produce 2 aircraft or 12 billion lines of code (software) with 1 unit of resources, and India can produce 1 aircraft or 8 billion lines of code

Table 1. Absolute advantage.

\begin{tabular}{ccc}
\hline & \multicolumn{2}{c}{ Output per unit of resources } \\
\hline Nation & Aircraft & $\begin{array}{c}\text { Software } \\
\text { (billion lines of code) }\end{array}$ \\
\hline United States & 2 & 12 \\
India & 1 & 8 \\
\hline
\end{tabular}


with 1 unit of resources. Assume that both the products in both the countries are comparable in quality. Under these circumstances, the US is a more productive and less costly supplier of both aircraft and software than India, since it produces more of each good from a unit of resources than India does. In other words, the US has an absolute cost advantage over India in the production of both of these goods.

However, according to Ricardo's principle of comparative advantage, even if a nation has an absolute cost advantage in the production of both the goods, the two nations can still mutually benefit if they engage in trade of these goods. The less efficient nation should specialize in and export the product in which it is relatively less inefficient, i.e., where its absolute disadvantage is least; while the more efficient nation should specialize in and export the product in which it is relatively more efficient, i.e., where its absolute advantage is greatest [16].

In other words, a country has a comparative advantage over another country in the production of a particular good if the cost of making this good, compared with the cost of making other goods, is lower in this country than in the other country. Under the above circumstances, the US has a comparative advantage over India in the production of aircraft. Why? Because the cost of a aircraft in the US is the same as the cost of 6 billion lines of code (since both require $1 / 2$ unit of resources), whereas in India it is the same as the cost of 8 billion lines of code (since both require 1 unit of resources). Thus, relative to the cost of producing other goods (in this case, software), aircraft are cheaper to produce in the US than in India.

By the same token, India has a comparative advantage in software production. The cost of 8 billion lines of code in India is the same as the cost of 1 aircraft (since both require 1 unit of resources), whereas in the US it is the same as the cost of 1 and $1 / 3$ aircraft (since both require $2 / 3$ unit of resources). Thus, relative to the cost of producing other goods (in this case, aircraft), software is cheaper to produce in India than in the United States.

If a country has a comparative advantage in the production of a particular good and if it can trade freely with other countries, it is likely to find that it can improve its economic lot by specializing in the production of this good and by importing those commodities for which it does not have a comparative advantage. For example, consider the US under the above circumstances. Figure 1 shows US's production possibilities curve ( $\left.P P^{\prime}\right)$ representing various amounts of aircraft and software it can produce with its existing resources and a set of indifference (utility) curves (IC1, IC2) representing different levels of consumer satisfaction or betterment of its economic $\operatorname{lot}^{1}$. The higher the indifference curve, the higher is the betterment level of the nation's economic lot. If the US cannot trade with India, perhaps because of protec-

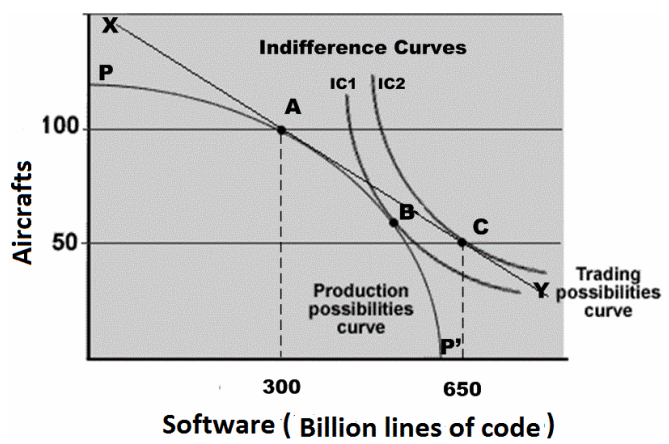

Figure 1. Economic benefits from free trade without foreign trade, production and consumption in the US are at point $B$, where indifference curve $I C 1$ is tangent to the production possibilities curve, $P P^{\prime}$. With trade, the US can move from point $A$ along the trading possibilities curve, $X Y$, to point $C$, and reach a higher indifference curve, IC2.

tionist measures (tariffs, quotas, and the like) in both countries, consumer satisfaction in the US will be maximized by choosing point $B$, where the marginal rate of substitution between the two commodities equals the marginal rate of transformation between them. Point $B$ is on indifference curve 1 (IC1).

Suppose now that free trade is permitted, and that the US is able to trade the good in which it has a comparative advantage, aircraft, for Indian software. The line $X Y$ in the figure called the US's trading possibilities curve, shows the various amounts of aircraft and software code that the US can end up with if it chooses point $A$ on its production possibilities curve, where it produces, say, 100 aircraft and 300 billion lines of code, and exports various amounts of its aircraft to India. The slope of line $X Y$ equals (in absolute value) the lines of Indian software code the US can get by giving up one unit of its aircraft. Assume that it is 7 billion lines of code for each aircraft-more than an aircraft's relative cost of production in the US ( 6 billion lines) and less than its relative cost of production in India ( 8 billion lines).

As shown in the Figure 1, US will increase consumer satisfaction if it moves along line $X Y$ from point $A$ to point $C$, where line $X Y$ is a tangent to the indifference curve $I C 2$. In this way, it reaches a higher indifference curve representing an increased level of betterment of its economic lot. At point $C$, US is producing 100 aircraft, but trading 50 aircraft for 350 billion lines of Indian software code-which is much more than what it could have produced at home by giving up the resources to make 50 aircraft (note that the point $C$ is outside the $P P^{\text {' }}$ curve). Since $I C 2$ is considerably higher than $I C 1$, US's consumers are much better-off than in the scenario when trade is not permitted.

${ }^{1}$ Readers unfamiliar with these economic concepts are referred to any college-level texts on Microeconomics such as (Mansfield, 1997) or on International Economics such as (Carbaugh, 2012). 
At the same time, India will increase consumer satisfaction if it specializes in the production of software (where it has a comparative cost advantage) and exports them to the US, while cutting back its production of aircraft and importing them from the United States. Thus, both countries will specialize in the production of those goods for which they have a comparative advantage and export them to the other country. This way, both countries attain a higher level of consumer satisfaction than the scenario when trade is not allowed. Although, for the sake of simplicity, we have used a trading model involving only two countries and only two goods, the theory of comparative advantage holds even if the trading model is expanded to many countries and many products. Further, beyond the national level, the theory of comparative advantage holds even at the industry or firm level [16].

A key underlying assumption of this trade theory is that the transportation or distribution costs are zero. This assumption may sound questionable or impractical as this cost may be substantial for physical goods such as an automobile, especially if the spatial difference between the trading nations is significant. But, when it comes to information or digital goods such as software, this is actually a very valid assumption. With recent advances in communications technology, namely the Internet, the cost of distributing information goods, even at the global level, has fallen substantially approaching almost "zero".

\section{Winners and Losers}

Thus, as can be seen, "offshore outsourcing" is not really bad for the US economy (rather, it is good) if one looks at it in the light of international trade. However, whereas free trade of this sort provides many benefits to people in both countries, not everyone gains from it. In our example, although the US aircraft industry (and the related work-force) may make significant gains, the US software workers, in particular, may be hurt considerably by the reduction (not elimination) in software output in the United States. Thus, it would not be surprising if this group of workers were to oppose offshore outsourcing and press for protection from imports.

In theory, the software producers in the US should also incur losses, but not necessarily if they are also the producers of software in India, which is true to a great extent. Almost all leading American hi-tech companies (e.g., GE, IBM, H-P, Texas Instruments, Intel, Microsoft, Oracle etc.) have presence in India. Compared to other physical goods such as an automobile or a computer (hardware), the digital goods such as software have some unique cost characteristics. One unique feature of information or digital goods is that they are costly to produce but very cheap to reproduce. In other words, production of infor- mation goods involves high fixed costs but very low variable costs [17]. Its total cost of production is dominated by the "First Copy Costs" (fixed costs). Once the first copy of an information good has been produced, the cost of creating an additional unit (marginal cost) is very small, almost "zero" if the product is "downloadable"; otherwise, perhaps the cost of stamping a CD. Further, and most notably, most of the fixed costs are sunk costs - costs that are not recoverable if the production is stopped. There is not much of a salvage value of flopped software! Thus, it becomes economically imperative that the software firms produce or source these products wherever they can do so in the most cost effective way.

Perhaps, this is why we hear a lot of resentment from the domestic software workers, but hardly any outcry from the software companies. This is why we hear a lot of hue and cry from populist politicians, but hardly any opposition from the business and economic leadership at the national level (just the opposite, in fact). An editorial in The Wall Street Journal underscores this point very well [18]. The editorial criticizes the New Jersey lawmakers for passing a bill that would ban all state contract work from being performed outside the country. It points out that the measure would not only mean a higher burden on taxpayers and artificially increase government expenditures, but it is also likely to end up costing more local jobs than it protects. For, if the state contractor's costs rise because it has to dismiss its low-cost overseas workforce, it will either have to drop the state contract, accept lower profits, or lay off other workers. It further opines that "the measure may also violate the US. Constitution, which bars states from having an independent foreign policy."

\section{Conclusions}

In summary, there is really nothing new happening under the sun! As discussed in this paper, "offshore outsourcing" could be viewed as essentially nothing but "international trade" and our country gains immensely from foreign trade, and so do businesses. Specifically, when it comes to digital goods such as software, because of their unique cost characteristics (both production and distribution), it becomes even more compelling for businesses to produce or source these products wherever they can do so in the most cost effective way.

While there has been a plethora of academic research done on topics such as critical success factors of outsourcing, including what motivates a company to outsource and what factors contribute to the success of outsourcing, research on the impact of outsourcing on the individual employee seems to be less prevalent. A literature review of ITO published in 2006 reviewed 131 ITO articles; only three of the 131 articles focused on the ef- 
fect of ITO on IS staff, and two of those were actually looking at contract employees within the company [19]. While some more articles have been published on the impact of outsourcing on the IT worker since 2006, research seems to be still limited on this topic.

In this regard, some practical relevant and interesting research areas might be to examine issues pertaining to the retraining of US workers and what IT skills are in most demand that are least likely to be outsourced. Another area for research could be examining the psychological impact of outsourcing on employees. For example: How does outsourcing impact remaining employees' motivation and commitment to the organization? How have jobs in the IT field changed because of outsourcing? Do these changes in IT jobs attract a different type of employee? Can theories used in studying downsizing and job turnover be used to study the impact of outsourcing on individual employees?

Although mass media and popular press continue to debate whether outsourcing is good or evil, given that the US is a champion of free trade, it is high time that we the IT community (professionals as well as academics) accept offshore outsourcing as a business reality which is here to stay. Instead of questioning the merits of offshore outsourcing, we are, perhaps, better off learning how to adapt to the changing work environments that offshore outsourcing creates.

\section{REFERENCES}

[1] S. Pearlstein, "Outsourcing: What's the True Impact? Counting Jobs Is Only Part of the Answer," Washington Post, 1 July 2012.

[2] P. Tambe and L. Hitt, "How Offshoring Affects IT Workers," Communications of the ACM, Vol. 53, No. 10, 2010, pp. 62-70. http://dx.doi.org/10.1145/1831407.1831426

[3] M. Cheon, V. Grover and J. Teng, "Theoretical Perspectives on the Outsourcing of Information Systems," Journal of Information Technology, Vol. 10, No. 4, 1995, pp. 209-219. http://dx.doi.org/10.1057/jit.1995.25

[4] P. Roberts, "A Greater Threat than Terrorism: Outsourcing the American Economy," 2010.

http://economyincrisis.org/content/greater-threat-terroris m-outsourcing-american-economy

[5] H. Wickford, "Negative Effects Outsourcing Has on Organizations," 2012.

http://smallbusiness.chron.com/negative-effects-outsourci ng-organizations-25351.html

[6] S. Hargreaves, "The Case for Outsourcing Jobs," CNN
Money, 2012.

http://money.cnn.com/2012/09/14/news/economy/outsour cing-jobs

[7] T. Hamburger, C. Loennig and Z. Goldfarb, "Obama's Record on Outsourcing Draws Criticism from the Left," Washington Post, 9 July 2012.

http://www.washingtonpost.com/business/economy/obam as-record-on-outsourcing-draws-criticism-from-the-left/2 012/07/09/gJQAljJCZW_story.html

[8] O. Williamson, "The Economic Institutions of Capitalism," The Free Press, New York, 1985.

[9] M. Lacity, S. Khan, A. Yan and L. Willcocks, “A Review of the IT Outsourcing Empirical Literature and Future Research Directions," Journal of Information Technology, Vol. 25, No. 4, 2010, pp. 395-433. http://dx.doi.org/10.1057/jit.2010.21

[10] J. Lee and Y. Kim, "Effect of Partnership Quality on IS Outsourcing Success: Conceptual Framework and Empirical Validation," Journal of Management Information Systems, Vol. 15, No. 4, 1999, pp. 29-61.

[11] O. Bertrand, "What Goes Around, Comes Around: Effects of Offshore Outsourcing on the Export Performance of Firms," Journal of International Business Studies, Vol. 42, 2011, pp. 334-344. http://dx.doi.org/10.1057/jibs.2010.26

[12] R. Hirscheim and M. Lacity, "The Myths and Realities of Information Technology Insourcing," Communications of the ACM, Vol. 43, No. 2, 2000, pp. 99-107. http://dx.doi.org/10.1145/328236.328112

[13] J. Dibbern, T. Goles, R. Hirschheim, and J. Bandula, "Information Systems Outsourcing: A Survey and Analysis of the Literature," Database for Advances in Information Systems, Vol. 34, No. 4, 2004, pp. 6-102. http://dx.doi.org/10.1145/1035233.1035236

[14] D. Di Gregorio, M. Musteen and D. Thomas, "Offshore Outsourcing as a Source of International Competitiveness for SMEs," Journal of International Business Studies, Vol. 40, 2009, pp. 969-988. http://dx.doi.org/10.1057/jibs.2008.90

[15] D. Ricardo, "The Principles of Political Economy and Taxation," Cambridge University Press, London, 1966.

[16] R. J. Carbaugh, "International Economics," 14th Edition, Cengage Learning, 2012.

[17] H. Varian, J. Farrell and C. Shapiro, "The Economics of Information Technology," Cambridge Press, Cambridge, 2005.

[18] “Editorial," The Wall Street Journal, 23 March 2005.

[19] R. Gonzalez, J. Gasco and J. Llopis, "Information Systems Outsourcing: A Literature Analysis," Information \& Management, Vol. 43, No. 7, 2006, pp. 821-834. http://dx.doi.org/10.1016/j.im.2006.07.002 